\title{
Isolation and characterization of the haemin- binding proteins from Neisseria meningitidis
}

\author{
B. Craig Lee
}

Tel: +1 4032204220 . Fax: +1 4032708520

Department of Microbiology and Infectious Diseases, University of Calgary, 3330 Hospital Drive NW, Calgary, Alberta, Canada T2N 4N1

\begin{abstract}
The mechanism of haem-iron acquisition in Neisseria meningitidis is poorly understood. Using haemin-agarose in a batch affinity chromatography method, two haemin-binding proteins of 97 and $50 \mathrm{kDa}$ were isolated from total membranes derived from Neisseria meningitidis B16B6 grown under irondeficient but not under iron-replete conditions. No binding proteins were affinity-purified when total membranes underwent limited proteolysis with trypsin, suggesting a haem-protein interaction. When biotinylated human haemoglobin was used as the affinity ligand, proteins of identical molecular mass were isolated. Detection of haemin-binding proteins in a whole cell binding assay demonstrated a surface-exposed location. Competitive binding studies indicated that this haem-protein interaction was specific, because only haemin or human haemoglobin, but not cytochrome $c_{111}$, protoporphyrin IX, iron-loaded human lactoferrin, iron-loaded human transferrin or $\mathrm{Fe}\left(\mathrm{NO}_{3}\right)_{3}$, could abrogate binding. The presence of similar haemin-binding proteins in a limited survey of clinical meningococcal strains indicated that the expression of the haemin-binding proteins is not serogroup-specific.
\end{abstract}

Keywords: Neisseria meningitidis, haemoglobin, haemin-binding proteins, meningococcal disease, iron

\section{INTRODUCTION}

Neisseria meningitidis, a Gram-negative diplococcus, is an obligate human mucosal pathogen (DeVoe, 1982). Meningococcal disease, whose principal clinical expression is meningitis, remains a significant global public health problem (Peltola, 1983; Greenwood, 1984). Whereas most meningococcal cases cluster in small focal outbreaks in industrialized countries (Schlech et al., 1985; Harrison \& Broome, 1987), the epidemiology of meningococcal meningitis in sub-Saharan Africa is characterized by cyclical waves of epidemic disease that occur at 10-12 year intervals (Peltola, 1983; Greenwood, 1984).

Iron is a determinant of virulence in the meningococci. The addition of iron-containing compounds, such as iron dextran (Holbein, 1980), transferrin iron (Holbein, 1981), or haemoglobin (Brodeur et al., 1985), enhances the lethality of meningococci in a murine model of infection. To acquire iron from the external environment, the meningococcus expresses surface-accessible ironregulated proteins that demonstrate binding specificity to the host iron-containing compounds human lactoferrin

Abbreviation: $\mathrm{HmBP}$, haemin-binding protein.
(Schryvers \& Morris, 1988b) and human transferrin (Schryvers \& Morris, 1988a). Receptors that exhibit such host specificity for these iron-sequestering glycoproteins have been identified in other pathogenic bacteria, such as $N$. gonorrboeae (Lee \& Schryvers, 1988; Lee \& Bryan, 1989), Haemophilus influenzae type b (Schryvers, 1989), and Actinobacillus pleuropneumoniae (Gonzalez et al., 1990). Cloning of the meningococcal (Irwin et al., 1993; Legrain et al., 1993) and gonococcal (Cornelissen et al., 1992) transferrin receptor protein genes has permitted the construction of isogenic receptor mutants that are functionally incapable of binding and using human transferrin as an iron source. This genetic evidence supports the contention that in the pathogenic Neisseriae, specific interaction of transferrin with its cognate receptor is a necessary prelude for transferrin iron uptake.

In contrast, the mechanism of haem-iron acquisition in $N$. meningitidis is poorly understood. Using a solid phase dot enzyme assay, an outer membrane iron-regulated haemoglobin-binding protein has been described in the meningococcus (Lee \& Hill, 1992). Competitive binding assays using haem and haem-containing compounds suggest that this binding protein recognizes the haem prosthetic group (Lee \& Hill, 1992). This observation, 
coupled with the recent demonstration of haemin-binding proteins (HmBPs) in N. gonorrhoeae (Lee, 1992a), suggests that haem-iron acquisition in the meningococcus may proceed via a siderophore-independent receptor-mediated pathway analogous to that of lactoferrin and transferrin iron, in which the initial event in haem-iron uptake involves the specific interaction with a cell surface $\mathrm{HmBP}(\mathrm{s})$. Therefore, the objective of this study was to isolate such surface accessible $\mathrm{HmBPs}$ in $N$. meningitidis and to determine the relationship of this component to the meningococcal haemoglobin-binding protein.

\section{METHODS}

Bacterial strains and growth conditions. N. meningitidis B16B6, a standard serotyping strain, is a serogroup $B$, serotype $2 A$, strain kindly provided by A. Schryvers (University of Calgary, Canada). Clinical meningococcal isolates representing serogroups A, C, W-135 and X, were obtained from The Provincial Laboratory of Public Health for Southern Alberta, Calgary, Canada. Bacteria were maintained as stock cultures in skimmed milk at $-70^{\circ} \mathrm{C}$, and, prior to use, organisms were grown on chocolate agar plates supplemented with $1 \%$ (v/v) CVA enrichment $(\mathrm{Gibco})$ at $35^{\circ} \mathrm{C}$ in an atmosphere containing $5 \%$ (v/v) $\mathrm{CO}_{2}$.

Chemicals. Human haemoglobin, equine cytochrome $c_{111}$, ironloaded human lactoferrin, iron-loaded human transferrin, bovine haemin, protoporphyrin IX, ferric nitrate, EDDA (ethylenediamine di-o-hydroxyphenylacetic acid), guanidine $\mathrm{HCl}$, and haemin-agarose were purchased from Sigma. All the iron- and haem-containing compounds were more than $95 \%$ pure according to the manufacturer. Streptavidin-horseradish peroxidase (SA-HRP) conjugate was purchased from BioCan Scientific. Desferrioxamine was obtained from Ciba-Geigy Canada. Trypsin was obtained from Sigma. With the exception of haemin, which was dissolved in a small volume of $10 \mathrm{mM}$ $\mathrm{NaOH}$, and protoporphyrin IX, which was solubilized in a small volume of $10 \mathrm{mM}$ acetic acid, all the iron-containing compounds and haemoproteins were solubilized in deionized water immediately prior to use.

Membrane preparation. Crude total membranes were prepared as previously described (Lee \& Hill, 1992) from cells grown in iron-replete [brain-heart infusion (BHI) broth (Difco)] and iron-limited (BHI broth rendered iron-deficient by the addition of an iron chelator, either EDDA or desferrioxamine, to a final concentration of $100 \mu \mathrm{M}$ ) conditions and from cells in which either bovine haemin (BHI broth supplemented with $12 \mu \mathrm{M}$ bovine haemin) or iron (BHI broth supplemented with $150 \mu \mathrm{M}$ $\left.\mathrm{Fe}\left(\mathrm{NO}_{3}\right)_{3}\right)$ served as the sole exogenous source of iron. The protein content was determined by the method of Lowry with bovine serum albumin as standard.

Haemin affinity chromatography. $\mathrm{HmBPs}$ were isolated by affinity-purification using haemin-agarose (Sigma) (Tsutsui \& Mueller, 1982) as the affinity resin in a batch method as described previously (Lee, 1992a; Lee, 1992b). In brief, crude total membrane, adjusted to a final concentration of $1 \mathrm{mg} \mathrm{ml}^{-1}$ in $50 \mathrm{mM}$ Tris/ $\mathrm{HCl}$ and $1 \mathrm{M} \mathrm{NaCl}(\mathrm{pH} 8.0)$, was incubated with $20 \mu \mathrm{mol}$ haemin-agarose at $25^{\circ} \mathrm{C}$ for $1 \mathrm{~h}$. Binding was performed at high ionic conditions to prevent non-specific interaction between the proteins and the affinity gel. The membrane was solubilized with the addition of sodium EDTA (pH 8.0) and Sarkosyl NL30 to a final concentration of $10 \mathrm{mM}$ and $0.75 \%(\mathrm{v} / \mathrm{v})$, respectively, for $1 \mathrm{~h}$ at $25^{\circ} \mathrm{C}$. The mixture was then centrifuged at $750 \mathrm{~g}$ for $5 \mathrm{~min}$, and the supernatant was discarded. The pelleted ligand affinity resin was washed three times either with a high-salt wash, consisting of $50 \mathrm{mM}$ Tris/ $\mathrm{HCl}$ and $1 \mathrm{M} \mathrm{NaCl}(\mathrm{pH} 8 \cdot 0$ ) or with a guanidine $\mathrm{HCl}$ wash, consisting of $500 \mathrm{mM}, 1 \mathrm{M}$, or $2 \mathrm{M}$ guanidine $\mathrm{HCl}$ in $50 \mathrm{mM}$ Tris $/ \mathrm{HCl}$ and $1 \mathrm{M} \mathrm{NaCl}(\mathrm{pH} 8 \cdot 0)$. Each of the above washes included sodium EDTA ( $5 \mathrm{mM}$ final concentration, $\mathrm{pH} 8.0$ ) and Sarkosyl NL30 (0.5\% final concentration). After a final low-salt wash [ $50 \mathrm{mM}$ Tris/ $\mathrm{HCl}$ and $100 \mathrm{mM} \mathrm{NaCl}(\mathrm{pH} \mathrm{8.0)}$ ] without EDTA and detergent, bound proteins were eluted by the addition of $2 \%(\mathrm{w} / \mathrm{v})$ SDS and $1 \%(\mathrm{v} / \mathrm{v}) \beta$-mercaptoethanol in $500 \mathrm{mM}$ Tris $/ \mathrm{HCl}(\mathrm{pH} \mathrm{6.8)}$ followed by boiling the affinity resin at $100{ }^{\circ} \mathrm{C}$ for $5 \mathrm{~min}$. The affinity gel was pelleted by centrifugation at $750 \mathrm{~g}$ for $5 \mathrm{~min}$. The supernatant was applied to a $12.5 \%$ polyacrylamide-SDS gel for analysis by SDS-PAGE.

Haemoglobin affinity purification of haemoglobin-binding proteins. Haemoglobin-binding proteins were isolated from iron-deficient total membranes by batch affinity purification analogous to the method used to isolate the meningococcal transferrin binding proteins (Schryvers \& Morris, 1988a). Human haemoglobin was biotinylated with NHS-S-S-biotin as described previously (Lee \& Hill, 1992). Retained proteins were eluted from the streptavidin-agarose affinity resin by the addition of $2 \%(\mathrm{w} / \mathrm{v})$ SDS and $1 \%(\mathrm{v} / \mathrm{v}) \beta$-mercaptoethanol in $500 \mathrm{mM}$ Tris/ $\mathrm{HCl}(\mathrm{pH} \mathrm{6.8)}$ and were separated by SDS-PAGE.

Whole-cell binding assay. Organisms were grown on chocolate agar for $12-14 \mathrm{~h}$ at $35^{\circ} \mathrm{C}$ in the presence of $5 \%(\mathrm{v} / \mathrm{v}) \mathrm{CO}_{2}$. Cells were scraped from plates and suspended in BHI broth containing $100 \mu \mathrm{M}$ EDDA to an initial $\mathrm{OD}_{600}$ of $0 \cdot 002$, as measured using a Pye Unicam PU8800 spectrophotometer (Unicam Analytical). These cultures were shaken at $35^{\circ} \mathrm{C}$ in the presence of $5 \% \mathrm{CO}_{2}$ or in an anaerobic chamber (model $800 \mathrm{~A}$, Anaerobe Systems, Santa Clara, CA, USA) rendered microaerophilic $(5 \%$ $\mathrm{O}_{2}, 10 \% \mathrm{CO}_{2}, 85 \% \mathrm{~N}_{2}$ ) until mid-exponential-phase growth was achieved $\left(\mathrm{OD}_{600} 0 \cdot 12-0 \cdot 14\right)$. Samples were removed to inoculate fresh BHI broth with and without $100 \mu \mathrm{M}$ EDDA to a starting $\mathrm{OD}_{600}$ of $0 \cdot 002$. Following this second growth cycle to ensure depletion of internal iron stores, samples were again removed at mid-exponential phase and $\mathrm{OD}_{600}$ was adjusted to $0 \cdot 25$. After washing at $4^{\circ} \mathrm{C}$ in $50 \mathrm{mM}$ Tris $/ \mathrm{HCl}(\mathrm{pH} 8 \cdot 0)$, the cells were resuspended in $1 \mathrm{ml}$ low-salt buffer and subjected to the affinity resin binding protocol as described above. Identical experiments were performed with $100 \mu \mathrm{M}$ desferrioxamine in lieu of EDDA as the iron chelator.

Specificity of the HmBPs. The binding specificity of the HmBPs was assessed by competition binding assays. Iron-deficient crude total membranes were preincubated for $1 \mathrm{~h}$ at $25^{\circ} \mathrm{C}$ with increasing concentrations of haemin, haem-containing and nonhaem-containing compounds prior to haemin affinity chromatography.

Proteolytic digestion of the $\mathbf{N}$. meningitidis HmBPs. Samples of crude total membranes prepared for the affinity-binding procedure were subjected to proteolytic digestion at $37^{\circ} \mathrm{C}$ with the addition of trypsin to a final concentration of either $25 \mu \mathrm{g}$ $\mathrm{ml}^{-1}$ or $50 \mu \mathrm{g} \mathrm{ml}^{-1}$. Proteolysis was stopped after $10 \mathrm{~min}$ with the addition of the serine protease inhibitor PMSF $(\mathrm{BDH})$ to a final concentration of $200 \mu \mathrm{g} \mathrm{ml}^{-1}$. Affinity chromatography was performed on the resultant digests.

Western blot analysis to detect haemoglobin-binding activity. Haemin-affinity-purified proteins $(25 \mu \mathrm{l})$ that were separated by SDS-PAGE were electroblotted at $10 \mathrm{~V}$ constant voltage for $12 \mathrm{~h}$ at $4{ }^{\circ} \mathrm{C}$ onto polyvinylidene difluoride (PVDF) membranes (Immobilon-P, $0 \cdot 45 \mu \mathrm{m}$, Millipore) by the method of Towbin et al. (1979) using a Bio-Rad MiniTransblot apparatus. The membrane was subsequently probed for the presence of haemoglobin-binding activity as previously de- 
scribed (Lee \& Hill, 1992). In brief, after blocking with $0.5 \%$ (w/v) skimmed milk in TBS $(50 \mathrm{mM}$ Tris/ $\mathrm{HCl}, \mathrm{pH} 7 \cdot 5,1 \mathrm{M}$ $\mathrm{NaCl}$ ), the membrane was incubated at $37^{\circ} \mathrm{C}$ for $1 \mathrm{~h}$ with $50 \mathrm{nM}$ biotinylated human haemoglobin followed by the addition of the SA-HRP conjugate at a concentration of $500 \mathrm{ng} \mathrm{ml}^{-1}$. The blot was developed with a chloronaphthol/hydrogen peroxide substrate mixture (HRP Reagent, Bio-Rad) for $10 \mathrm{~min}$. The paper was washed with water to stop the reaction.

Electrophoresis. Proteins from affinity-purified total membranes or affinity-purified whole cells were analysed by SDSPAGE with the discontinuous buffer system of Laemmli (1970). The resolving gel was $12.5 \%$ acrylamide and the stacking gel was $5 \%$ acrylamide with $0.8 \%$ bisacrylamide. Gels were electrophoresed at $150 \mathrm{~V}$ constant voltage for $1 \mathrm{~h}$ on a Bio-Rad minigel apparatus. Gels were stained with silver (Oakley et al., 1980). Molecular masses were determined by using known proteins as standards.

\section{RESULTS}

\section{Purification of HmBPs from N. meningitidis B16B6}

Two HmBPs of molecular mass 97 and $50 \mathrm{kDa}$ were isolated by haemin affinity chromatography (Fig. 1, lane 1). The $97 \mathrm{kDa}$ protein on occasion migrated as an apparent doublet under reducing SDS-PAGE. However,

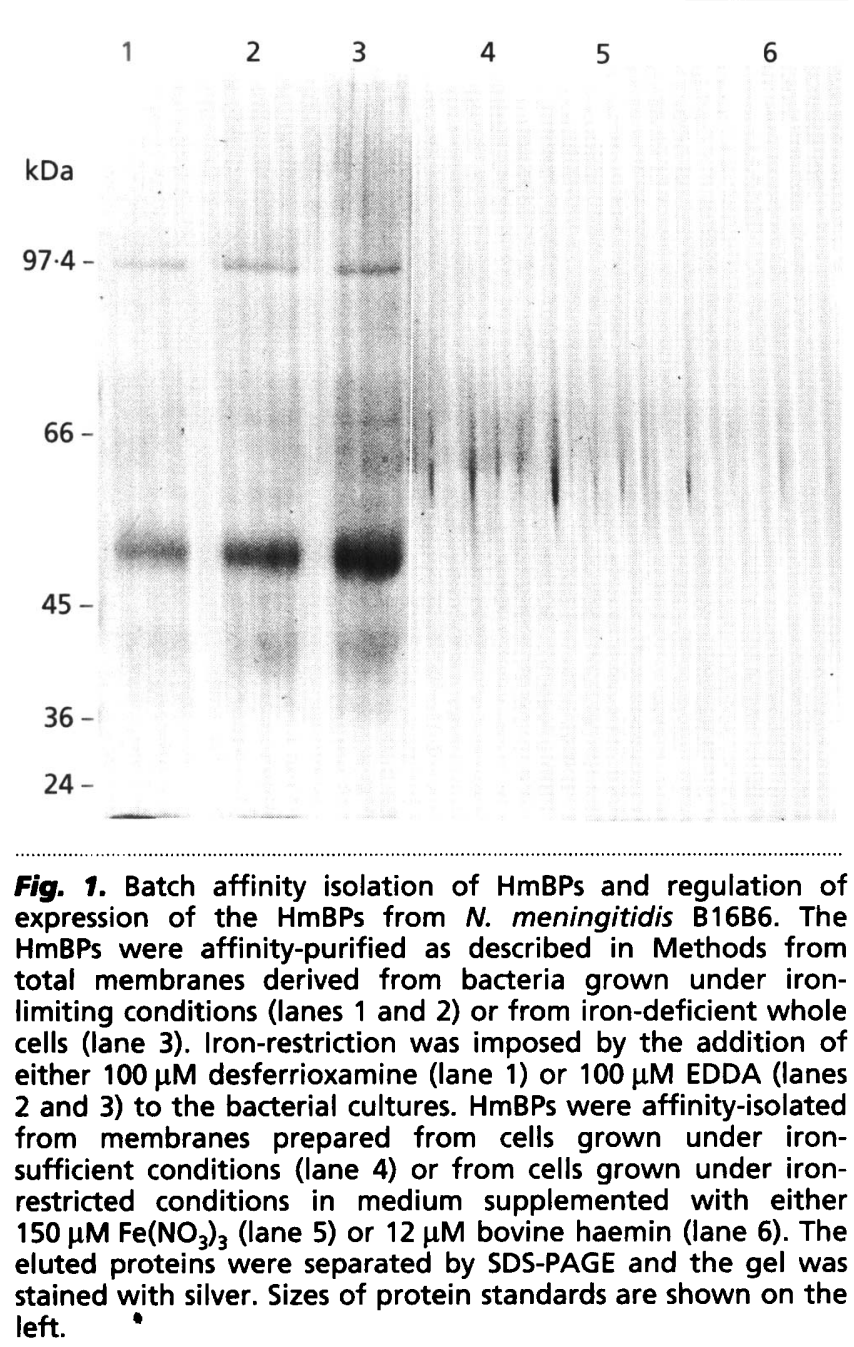

this protein resolved to a single band when the amount of affinity-purified total membranes loaded onto the polyacrylamide gel was progressively reduced (data not shown). Two other observations also suggested that the appearance of the doublet could be attributed to sample overload and not due to a second affinity-purified protein co-migrating with the $97 \mathrm{kDa} \mathrm{HmBP}$. Firstly, neither the addition of fresh $\beta$-mercaptoethanol to the samples nor the substitution of dithiothreitol as the reducing agent altered the migration characteristics of the $97 \mathrm{kDa}$ doublet (data not shown). Secondly, analysis of the affinitypurified proteins using a 4-20\% polyacrylamide gradient in the separating gel did not result in a further separation of the apparent doublet (data not shown). An alternative explanation for the anomalous migratory and tinctorial characteristics of the $97 \mathrm{kDa}$ protein may be the presence of an attached carbohydrate and/or phospholipid moiety. Another meningococcal outer membrane iron-binding receptor, tbp2, has been shown to be a lipoprotein (A. B. Schryvers, unpublished study). Additionally, partial proteolytic degradation of the $97 \mathrm{kDa} \mathrm{HmBP}$ could account for the doublet appearance.

The HmBPs were only detected under conditions of iron limitation (Fig. 1, lane 2). Their expression was independent of the iron chelator used to impose iron depletion (Fig. 1, lane 1). In contrast, no HmBPs were isolated from total membranes grown under iron-rich conditions (Fig. 1, lane 4). Similarly, when iron-restriction was reversed with the addition of $150 \mu \mathrm{M} \mathrm{Fe}\left(\mathrm{NO}_{3}\right)_{3}$ (Fig. 1 , lane 5), or when $12 \mu \mathrm{M}$ bovine haemin was provided as the sole exogenous iron source (Fig. 1, lane 6), no HmBPs were affinity-purified from these membranes. These results indicated that the expression of the HmBPs is ironregulated. The inability to isolate $\mathrm{HmBPs}$ from total membranes grown in the presence of bovine haemin as the sole iron source suggests that haemin may also regulate the expression of the HmBPs. Alternatively, the presence of haemin in the total membrane mixture may have competitively inhibited binding of the HmBPs to the affinity gel, and precluded their subsequent isolation.

No HmBPs could be affinity-isolated from iron-sufficient cultures grown either under microaerophilic conditions or at $25^{\circ} \mathrm{C}$ (data not shown). These results suggested that the expression of the HmBPs is neither governed by oxygen deprivation nor by slow growth rate.

The HmBPs were absent when the affinity resin alone, without applied membranes, was subjected to the affinity protocol, indicating that the HmBPs are neither degradation products nor derivatives of the agarose matrix (data not shown). The binding of the HmBPs to their ligand is a conformation-dependent process, since detergent solubilization of the membranes with the ionic detergent SDS prior to binding to the matrix-bound haemin also prevented isolation of the HmBPs (data not shown). Two explanations may account for the protein bands of $60-70 \mathrm{kDa}$ seen in the gels. Firstly, they may represent contaminating proteins present in the $\beta$ mercaptoethanol used in the elution buffer, as these bands were only present when this reducing agent was included 
(a)

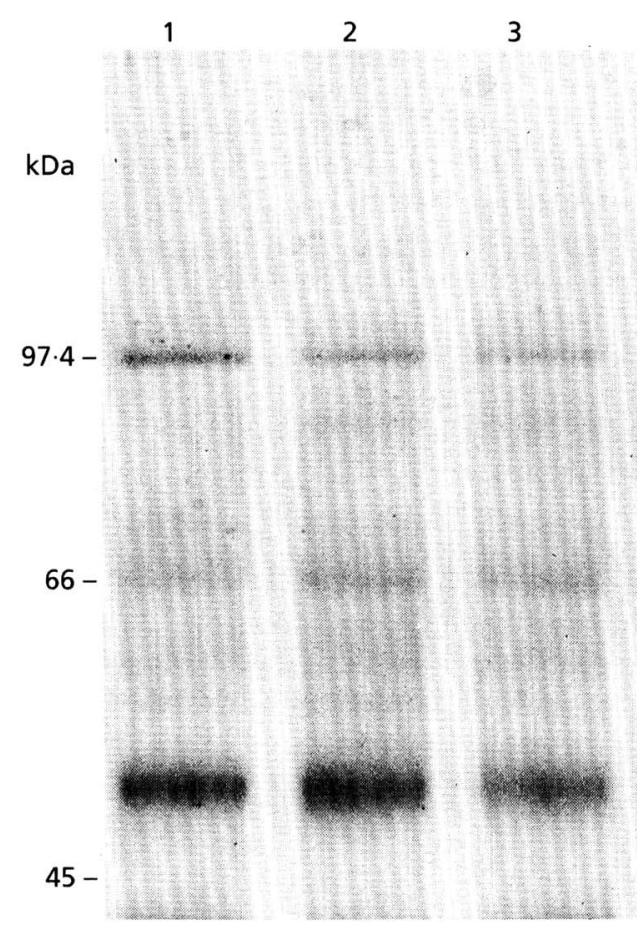

(b)

4

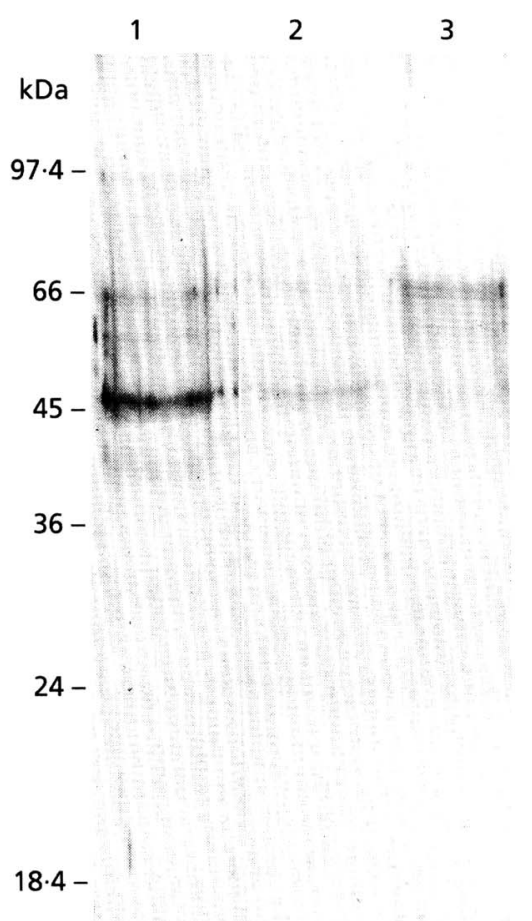

Fig. 2. (a) Haemin competition binding of the HmBPs. Bovine haemin at $0 \mu \mathrm{M}$ (lane 1), $1 \mu \mathrm{M}$ (lane 2), 10 $\mu \mathrm{M}$ (lane 3) and $1 \mathrm{mM}$ (lane 4) was incubated for $1 \mathrm{~h}$ at $25^{\circ} \mathrm{C}$ with $1 \mathrm{mg}$ total membranes prepared from iron-limited cultures of $N$. meningitidis B16B6. The HmBPs from these preparations were affinity-purified and separated by SDS-PAGE. The gel was stained with silver. Sizes of protein standards are shown on the left. (b) Haemoglobin competition binding of the HmBPs. Human haemoglobin at $0 \mu \mathrm{M}$ (lane 1), $1 \mu \mathrm{M}$ (lane 2) and $10 \mu \mathrm{M}$ (lane 3) was incubated with a constant amount (1 mg) of iron-limited total membranes of $N$. meningitidis B16B6 for $1 \mathrm{~h}$ at $25^{\circ} \mathrm{C}$. The $\mathrm{HmBPs}$ were affinity-isolated and separated by SDS-PAGE. The resultant gel was stained with silver. Sizes of protein standards are shown on the left.

in the elution buffer (data not shown) and were absent when it was omitted (data not shown) (Tasheva \& Dessev, 1983). Secondly, because such bands were occasionally seen in samples electrophoresed using other reducing agents, such as dithiothreitol (data not shown), they may represent artifactual keratin protein contaminants (Ochs, 1983; Merril, 1990).

To determine which component of the HmBPs bound directly to haemin, the haemin affinity resin containing the bound proteins was subjected to washes of increasing stringency with guanidine $\mathrm{HCl}$. No quantitative or qualitative differences were seen in the $\mathrm{HmBPs}$ that were eluted after washing with $500 \mathrm{mM}, 1 \mathrm{M}$ or $2 \mathrm{M}$ guanidine $\mathrm{HCl}$ (data not shown), indicating that there was no preferential retention of either $\mathrm{HmBP}$ on the affinity matrix.

\section{Cellular location of the HmBPs}

Isolation of $\mathrm{HmBPs}$ from whole-cells grown under ironlimited conditions (Fig. 1, lane 3) but not from wholecells grown under iron-rich conditions (data not shown) indicated that the HmBPs were both surface-exposed and iron-regulated. The conditions used in the whole-cell assay have previously been shown to maintain whole-cell integrity (Lee \& Hill, 1992). The minimal cell lysis present excluded significant contamination of the whole- cell samples with intracellular sequestered haem-containing proteins, such as cytochrome proteins.

\section{Specificity of the meningococcal HmBPs}

The specificity of the HmBPs for haemin was addressed in a series of competition binding experiments. The binding of the HmBPs to the immobilized haemin was specifically blocked by unlabelled haemin in a concentrationdependent manner (Fig. 2a, lanes 1-3). Haemin concentrations in excess of $10 \mu \mathrm{M}$ markedly diminished binding of the HmBPs to the haemin-agarose. This binding specificity extended to human haemoglobin. The presence of this haemoprotein at concentrations above $1 \mu \mathrm{M}$ also reduced adsorption of the $\mathrm{HmBPs}$ to the affinity gel (Fig. $2 \mathrm{~b}$, lanes 1-3). The aggregation of tetrapyrroles in aqueous solutions at physiological $\mathrm{pH}$ (Brown et al., 1976; Muller-Eberhard \& Nikkila, 1989) may account for the diminished ability of haemin relative to haemoglobin to inhibit binding competitively. This property could result in the formation of stacked haemin aggregates that would reduce the effective concentration of binding.

In contrast, no binding inhibition was observed when iron-restricted total membranes prepared from N. meningitidis $\mathrm{B} 16 \mathrm{~B} 6$, or from a serogroup $\mathrm{C}$ meningococcal isolate, were preincubated with another haem-containing protein, 


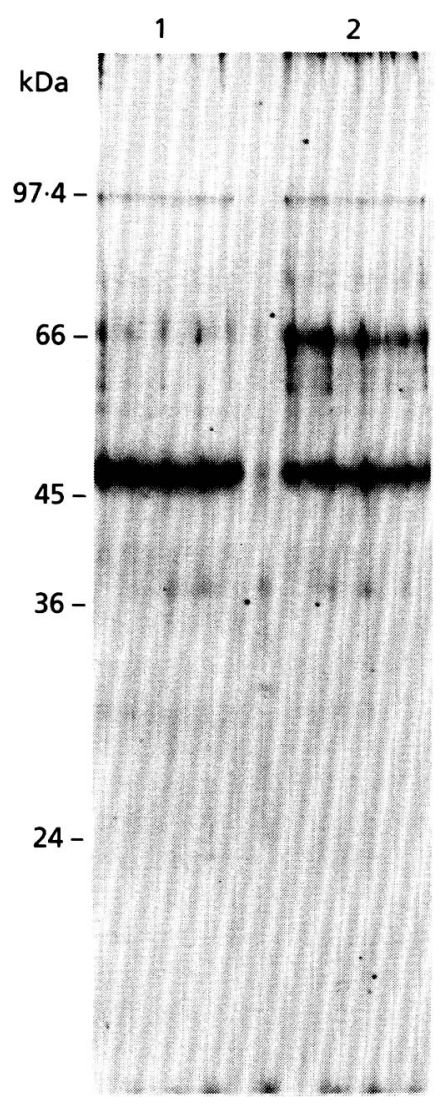

Fig. 3. Haemoglobin-binding proteins affinity-purified from $N$. meningitidis B16B6. Haemoglobin-binding proteins were isolated from iron-limited crude total membranes by batch haemoglobin-affinity chromatography as described in Methods (lane 1). The same membranes were subjected to haeminaffinity purification (lane 2). Retained proteins were eluted and separated by SDS-PAGE. The gel was stained with silver. Sizes of protein standards are shown on the left.

equine cytochrome $c_{111}$ (data not shown). The functional correlates of this binding specificity demonstrate this correspondence and have been shown in a previous study (Lee \& Hill, 1992). At concentrations of $10 \mu \mathrm{M}$, protoporphyrin IX, the immediate precursor of haem in the haem biosynthetic pathway, was incapable of blocking binding (data not shown). Two non-haem iron-containing glycoproteins, iron-loaded human lactoferrin and ironloaded human transferrin, and $\mathrm{Fe}\left(\mathrm{NO}_{3}\right)_{3}$ at concentrations of $10 \mu \mathrm{M}$ also did not competitively inhibit binding of the HmBPs to the haemin-bound polysaccharide matrix (data not shown).

\section{Proteolytic assays}

No $\mathrm{HmBPs}$ were purified when total membranes were incubated with either 25 or $50 \mu \mathrm{g} \mathrm{ml}^{-1}$ of trypsin for $30 \mathrm{~min}$ at $37^{\circ} \mathrm{C}$ prior to affinity isolation (data not shown). This observation indicates that either a protein determinant(s) is necessary for the interaction of the HmBPs with their ligand or that preservation of the surrounding protein architecture is necessary for binding.

\section{Isolation of $\mathrm{HmBPs}$ from other meningococcal strains}

$\mathrm{HmBPs}$ with molecular masses similar to those found in N. meningitidis B16B6 were affinity-purified from ironlimited total membranes prepared from representative strains belonging to serogroups A, C, X and W-135 (data not shown). This result suggests that these polypeptides are structurally and functionally conserved among clinically significant meningococcal serogroups.

\section{Isolation of haemoglobin-binding protein(s) from $N$. meningitidis B16B6}

Two haemoglobin-binding proteins (Fig. 3, lane 1) corresponding to the molecular masses of the HmBPs (Fig. 3, lane 2) were isolated from iron-limited total membranes by haemoglobin-affinity chromatography. This result suggests that a structural homology exists between the haemoglobin- and haemin-binding proteins. In an attempt to demonstrate a functional identity between the two binding proteins, PVDF membranes containing electroblotted SDS-PAGE separated $\mathrm{HmBPs}$, and nitrocellulose/cellulose acetate paper (Immobilon-NC, $0.45 \mu \mathrm{m}$ HAHY paper, Millipore) containing $1 \mu \mathrm{l}$ samples of immobilized HmBPs, were probed with biotinylated human haemoglobin. No haemoglobin-binding activity was seen in either blot (data not shown). The apparent conformation-dependent interaction between the HmBPs and their ligand (see above) provides an explanation for the lack of functional haemoglobin-binding activity in either denatured preparation.

\section{DISCUSSION}

Haemin and haem-containing compounds can promote the in vitro growth of many human bacterial pathogens (Perry \& Brubaker, 1979; Helms et al., 1984; Stull, 1987; Pidcock et al., 1988; Stoebner \& Payne, 1988; Daskaleros et al., 1991; Lee, 1991). For Porphyromonas gingivalis (Bramanti \& Holt, 1992a, b), N. gonorrboeae (Lee, 1992a), and $H$. influenzae type b (Lee, 1992b), this ability to use haem and haemoproteins as the sole exogenous iron source has been attributed to the presence of a surfaceexposed outer membrane haemin-binding protein(s) whose expression is governed by iron. In part because of the biochemical constraints imposed by free haem (Muller-Eberhard \& Nikkila, 1989; Vincent, 1989), it has been proposed that the specific binding of haem to these outer membrane constituents is a necessary prelude for the uptake of haem-iron (Bramanti \& Holt, 1992a; Lee, 1992a, b). The identification of two meningococcal surface-exposed iron-regulated haemin-binding proteins in this study is consistent with the supposition that haem-iron uptake may proceed via such a receptormediated process in N. meningitidis. The recent genetic demonstrations that haemin uptake in Yersinia enterocolitica (Stojiljkovic \& Hantke, 1992) and in Vibrio cholerae (Henderson \& Payne, 1993) requires a haemin-specific iron-regulated outer membrane receptor support this contention.

Using a solid-phase dot enzyme binding assay, in which biotinylated human haemoglobin was used to probe iron- 
limited meningococcal whole-cells and total membranes for haemoglobin-binding activity, a previous investigation reported the presence of an outer membrane haemoglobin-binding protein(s) in $N$ meningitidis (Lee \& Hill, 1992). Several lines of evidence suggest that the HmBPs isolated in this study represent these putative haemoglobin-binding proteins. Firstly, a functional identity exists between the two binding proteins, since irrespective of whether haemin or haemoglobin is used as the affinity ligand, proteins of the same size are affinitypurified from iron-deficient total membranes (Fig. 3, lanes 1 and 2). Secondly, despite quantitative differences attributable to methodological considerations, the binding specificities of the two binding proteins display a reciprocal relationship. Human haemoglobin is capable of inhibiting binding of the HmBPs to haemin-agarose (Fig. $2 \mathrm{~b}$, lanes 1-3), whereas haemin competitively inhibits haemoglobin-binding activity in a concentration-dependent manner (Lee \& Hill, 1992). As previously proposed (Lee \& Hill, 1992), this latter property suggests that the haem prosthetic group in haemoglobin is the ligand recognized by the haemoglobin-binding protein(s). Thirdly, the haemin- and haemoglobin-binding proteins share qualitatively similar inhibition profiles. Cytochrome $c_{111}$, protoporphyrin IX, iron-loaded human lactoferrin, iron-loaded human transferrin, and iron cannot competitively block binding (data not shown) (Lee \& Hill, 1992). Lastly, although it is unknown whether both polypeptides interact directly with haemin, the presence of two meningococcal haemoglobin-binding proteins is compatible with the two component model of binding (Smith \& Ledford, 1988) as predicted by Scatchard plot analysis (Scatchard, 1946) of the haemoglobin-binding proteins (Lee \& Hill, 1992).

All these observations suggest that the existence of discrete haemoglobin-binding proteins that are distinct from the HmBPs identified in this study may not be warranted. This evidence also implies that haemoglobinbinding activity in the meningococcus functions as a surrogate marker for the HmBPs. The suggestion that haem- and haemoglobin-iron uptake may be mediated by binding to a common receptor is reinforced by the observation in $V$. cholerae, in which iron utilization from haem and haemoglobin appears to require the synthesis of at least two proteins, one of which is an iron-regulated outer membrane protein proposed to act as a haem receptor (Henderson \& Payne, 1993).

The HmBPs in the pathogenic Neisseria species share several common properties, leading to the premise that the meningococcal polypeptides may represent the structural and functional homologues of the gonococcal HmBPs. The size of the meningococcal HmBPs closely resembles their gonococcal counterparts, in which the corresponding $\mathrm{HmBPs}$ are $97 \mathrm{kDa}$ and $44 \mathrm{kDa}$ (Lee, 1992a). Both meningococcal and gonococcal HmBPs possess quantitatively similar competitive inhibition profiles for haemin, haemoglobin, and for the non-haemcontaining glycoproteins hLf and hTf (Lee, 1992a). The discrepancy in the ability of cytochrome $c_{111}$ to inhibit binding competitively is unexplained but may reside in strain differences as only one gonococcal isolate was examined (Lee, 1992a). These analogies in the HmBPs are reminiscent of comparisons between another iron-repressible neisserial outer membrane protein receptor, the meningococcal and gonococcal transferrin (Tf) receptor, in which similarities are present not only in the structure and functional specificity of the meningococcal and gonococcal Tf receptors (Cornelissen et al., 1992), but also in the genomic organization and nucleotide sequences of their respective Tf receptor genes (Legrain et al., 1993).

The mechanisms responsible for the apparent similarities in structure and function of the HmBPs, and of the Tf receptor, in the pathogenic Neisseria are unknown. The observations that Neisseria species are naturally competent for transformation and that the selectivity for DNA uptake is restricted at a genus, but not at a species level (Dougherty et al., 1979), lead to the intriguing speculation that interspecies transformation-mediated localized recombinational events may account for such similarities. The gonococcus and meningococcus occupy the same ecological niches (Faur et al., 1975), providing the opportunities for such a horizontal exchange of genetic material. This molecular mechanism underlies the mosaic structure in the penicillin-binding protein 2 genes $($ pen $A)$ from N. gonorrboeae and N. meningitidis (Spratt, 1988; Spratt et al., 1989) whereby the pen $A$ genes in penicillinresistant organisms contain blocks of DNA recruited from either $N$. flavescens or $N$. cinerea (Spratt et al., 1992). However, there is currently no genetic evidence to attribute this mechanism as being responsible for the apparent structural and functional homology of the $\mathrm{HmBPs}$ in the gonococcus and meningococcus.

It is becoming more apparent that the meningococcus and gonococcus express a diverse array of iron-regulated surface-exposed binding proteins that interact specifically with host iron-containing compounds (Lee \& Schryvers, 1988; Schryvers \& Morris, 1988a, b; Lee \& Bryan, 1989; Lee, 1992a). The iron-regulated expression of surfaceaccessible haemin-specific binding proteins in the meningococcus described in this study supports this supposition. Although the contribution from exogenous siderophore sources is unknown (West \& Sparling, 1987), these pathogenic bacteria may satisfy their iron requirements by acquiring this critical element exclusively through iron uptake systems mediated by the specific binding of host iron-containing proteins to these receptors. However, the role of these receptors, and of the HmBPs in particular, in the pathogenesis of meningococcal and gonococcal disease will await further rigorous genetic analysis.

\section{ACKNOWLEDGEMENTS}

I thank A. B. Schryvers for providing the meningococcal strains. This work was supported by the Alberta Heritage Foundation for Medical Research.

\section{REFERENCES}

Bramanti, T. E. \& Holt, S. C. (1992a). Effect of porphyrins and host iron transport proteins on outer membrane protein expression in 
Porphyromonas (Bacteroides) gingivalis: identification of a novel 26kDa hemin-repressible surface protein. Microb Pathog 13, 61-73.

Bramanti, T. E. \& Holt, S. C. (1992b). Localization of a Porphyromonas gingivalis 26-kilodalton heat-modifiable, hemin-regulated surface protein which translocates across the outer membrane. $J$ Bacteriol 174, 5827-5839.

Brodeur, B. R., Larose, Y., Tsang, P., Hamael, J., Ashton, F. \& Ryan, A. (1985). Protection against infection with Neisseria meningitidis group $\mathrm{B}$ serotype $2 \mathrm{~b}$ by passive immunization with serotypespecific monoclonal antibody. Infect Immun 50, 510-516.

Brown, S. B., Shillock, M. \& Jones, P. (1976). Equilibrium and kinetic studies of the aggregation of porphyrins in aqueous solutions. Biocbem J 153, 279-285.

Cornelissen, C. N., Biswas, G. D., Tsai, J., Parachuri, D. K., Thompson, S. A. \& Sparling, P. F. (1992). Gonococcal transferrin-binding protein 1 is required for transferrin utilization and is homologous to TonB-dependent outer membrane receptors. $J$ Bacteriol 174, 5788-5797.

Daskaleros, P. A., Stoebner, J. A. \& Payne, S. M. (1991). Iron uptake in Plesiomonas shigelloides: cloning of the genes for the hemeiron uptake system. Infect Immun 59, 2706-2711.

Devoe, I. (1982). The meningococcus and mechanisms of pathogenicity. Microbiol Rev 46, 162-190.

Dougherty, T. J., Asmus, A. \& Tomasz, A. (1979). Specificity of DNA uptake in genetic transformation of gonococci. Biochem Biophys Res Commun 86, 97-104.

Faur, Y. C., Weisburd, M. H. \& Wilson, M. E. (1975). Isolation of Neisseria meningitidis from the genitourinary tract and anal canal. $J$ Clin Microbiol 2, 178-182.

Gonzalez, G. C., Caamano, D. L., \& Schryvers, A. B. (1990). Identification and characterization of a porcine-specific transferrin receptor in Actinobacillus pleuropneumoniae. Mol Microbiol 4, 1173-1179.

Greenwood, B. M. (1984). Selective primary health care: strategies for control of disease in the developing world: XIII. Acute bacterial meningitis. Rev Infect Dis 6, 374-389.

Harrison, L. H. \& Broome, C. V. (1987). The epidemiology of meningococcal meningitis in the civilian U.S. population. In The Evolution of Meningococcal Disease, pp. 27-46. Edited by N. A. Vedros. Boca Raton, Florida: CRC Press.

Helms, S. D., Oliver, J. D. \& Travis, J. C. (1984). The role of heme compounds and haptoglobin in Vibrio vulnificus pathogenicity. Infect Immun 45, 345-349.

Henderson, D. P. \& Payne, S. M. (1993). Cloning and characterization of the Vibrio cholerae genes encoding the utilization of iron from haemin and haemoglobin. Mol Microbiol 7, 461-469.

Holbein, B. E. (1980). Iron-controlled infection with Neisseria meningitidis in mice. Infect Immun 29, 886-891.

Holbein, B. E. (1981). Enhancement of Neisseria meningitidis infection in mice by the addition of iron bound to transferrin. Infect Immun 34, 120-125.

Irwin, S. W., Averill, N., Cheng, C. Y. \& Schryvers, A. B. (1993). Preparation and analysis of isogenic mutants in the transferrin receptor protein genes, $t b p 1$ and $t b p 2$, from Neisseria meningitidis. Mol Microbiol 8, 1125-1133.

Laemmli, U. K. (1970). Cleavage of structural proteins during the assembly of the head of bacteriophage T4. Nature 227, 680-685.

Lee, B. C. (1991). Iron sources for Haemophilus ducreyi. J Med Microbiol 34, 317--322.
Lee, B. C. (1992a). Isolation of heme-binding proteins of Neisseria gonorrboeae. J Med Microbiol 36, 121-127.

Lee, B. C. (1992b). Isolation of an outer membrane haemin-binding protein from Haemophilus influenzae type b. Infect Immun 60, 810-816.

Lee, B. C. \& Bryan, L. E. (1989). Identification and comparative analysis of the lactoferrin and transferrin receptors among clinical isolates of gonococci. J Med Microbiol 28, 199-204.

Lee, B. C. \& Hill, P. (1992). Identification of an outer membrane haemoglobin-binding protein in Neisseria meningitidis. $J$ Gen Microbiol 138, 2647-2656.

Lee, B. C. \& Schryvers, A. B. (1988). Specificity of the lactoferrin and transferrin receptors in Neisseria gonorrboeae. Mol Microbiol 2, $827-829$.

Legrain, M., Jacobs, E., Irwin, S. W., Schryvers, A. B. \& QuentinMillet, M. J. (1993). Molecular cloning and characterization of Neisseria meningitidis genes encoding the transferrin binding proteins Tbp1 and Tbp2. Gene 130, 73-80.

Merril, C. R. (1990). Silver staining of proteins and DNA. Nature 343, 779-780.

Muller-Eberhard, U. \& Nikkila, H. (1989). Transport of tetrapyrroles by proteins. Semin Hematol 26, 86-104.

Oakley, B. R., Kirsch, D. R. \& Morris, N. R. (1980). A simplified ultrasensitive silver stain for detecting proteins in polyacrylamide gels. Anal Biochem 105, 361-363.

Ochs, D. (1983). Protein contaminants of sodium dodecyl sulfatepolyacrylamide gels. Anal Biochem 135, 470-474.

Peltola, H. (1983). Meningococcal disease: still with us. Rev Infect Dis 5, 71-91.

Perry, R. D. \& Brubaker, R. R. (1979). Accumulation of iron by Yersiniae. J Bacteriol 137, 1290-1298.

Pidcock, K. A., Wooten, J. A., Daley, B. A. \& Stull, T. L. (1988). Iron acquisition in Haemopbilus influenzae. Infect Immun 56, 721-725.

Scatchard, G. (1946). The attraction of proteins for small molecules and ions. Ann NY Acad Sci 51, 660-672.

Schlech, W. F., III, Ward, J. I., Band, J. D., Hightower, A., Fraser, D. W. \& Broome, C. V. (1985). Bacterial meningitis in the United States, 1978 through 1981. JAMA 253, 1749-1754.

Schryvers, A. B. (1989). Identification of the transferrin- and lactoferrin-binding proteins in Haemophilus infuenzae. $J$ Med Microbiol 29, 121-130.

Schryvers, A. B. \& Morris, L. J. (1988a). Identification and characterization of the transferrin receptor from Neisseria meningitidis. Mol Microbiol 2, 281-288.

Schryvers, A. B. \& Morris, L. J. (1988b). Identification and characterization of the human lactoferrin-binding protein from Neisseria meningitidis. Infect Immun 56, 1144-1149.

Smith, A. \& Ledford, B. E. (1988). Expression of the haemopexintransport system in cultured mouse hepatoma cells. Biochem J 256, 941-950.

Spratt, B. G. (1988). Hybrid penicillin-binding proteins in penicillin-resistant strains of Neisseria gonorrboeae. Nature 332, 173-176.

Spratt, B. G., Zhang, Q.-Y., Jones, D. M., Hutchison, A., Brannigan, J. A. \& Dowson, C. G. (1989). Recruitment of a penicillinbinding protein gene from Neisseria flavescens during the emergence of penicillin resistance in Neisseria gonorrboeae. Proc Nat Acad Sci US A 86, 8988-8992.

Spratt, B. G., Bowler, L. D., Zhang, Q.-Y., Zhou, J. \& Maynard Smith, J. (1992). Role of interspecies transfer of chromosomal genes 
in the evolution of penicillin resistance in pathogenic and commensal Neisseria species. J Mol Evol 34, 115-125.

Stoebner, J. A. \& Payne, S. M. (1988). Iron-regulated haemolysin production and utilization of heme and hemoglobin by Vibrio cholerae. Infect Immun 56, 2891-2895.

Stojiljkovic, I. \& Hantke, K. (1992). Hemin uptake system of Yersinia enterocolitica: similarities with other TonB-dependent systems in Gram-negative bacteria. EMBO J 11, 4359-4367.

Stull, T. L. (1987). Protein sources of heme for Haemopbilus influenzae. Infect Immun 55, 148-153.

Tasheva, B. \& Dessev, G. (1983). Artifacts in SDS-polyacrylamide gel electrophoresis due to 2-mercaptoethanol. Anal Biochem 129, 98-102.

Towbin, H., Staehlin, T. \& Gordon, J. (1979). Electrophoretic transfer of proteins from polyacrylamide gels to nitrocellulose sheets: procedure and some applications. Proc Nat Acad Sci US A 76, 4350-4354.

Tsutsui, K. \& Mueller, G. C. (1982). Affinity chromatography of heme-binding proteins: an improved method for the synthesis of hemin-agarose. Anal Biochem 121, 244-250.

Vincent, S. H. (1989). Oxidative effects of heme and porphyrins on proteins and lipids. Semin Hematol 26, 105-113.

West, S. E. H. \& Sparling, P. F. (1987). Aerobactin utilization by Neisseria gonorrboeae and cloning of a genomic DNA fragment that complements Escherichia coli fhuB mutations. J Bacteriol 169, 3414-3421.

Received 2 September 1993; revised 26 November 1993; accepted 10 January 1994. 